\title{
Budapest agglomerációs konferencia - nyitott kérdésekkel
}

\section{Budapest agglomeration conference - with open questions}

\author{
FÖLDI ZSUZSA
}

Budapest Főváros Önkormányzatának agglomerációs tanácsnoka 2011 őszén azzal a kéréssel fordult a MTA Regionális Kutatások Központja Közép- és Észak-magyarországi Tudományos Intézetéhez ${ }^{1}$, hogy közösen szervezzenek szakmai fórumot Budapest és agglomerációs gyürüje komplex, számos problémával terhelt és ritkábban sikeres együttműködéssel is jellemezhető viszonyának áttekintésére. A szakmai együttműködésből, ha a vártnál később is, végül nagyszabású konferencia született tizenegy előadóval és százötven résztvevővel. Az Újvárosháza dísztermében 2012. április 26-án megrendezett eseményt jelentős sajtónyilvánosság követte, és a Magyar Építész Kamara továbbképzési rendszerében is akkreditálta.

A konferenciát megelőzően, 2012 elején olyan változások következtek be, amelyek még aktuálisabbá tették a tájékoztatás és a párbeszéd megindítását a témában. Január 1-jén lépett hatályba a területfejlesztésről és a területrendezésről szóló törvény módosítása, amellyel megszunntek a regionális fejlesztési tanácsok, a megyei területfejlesztési tanácsok, a kistérségi fejlesztési tanácsok, valamint a Budapesti Agglomerációs Fejlesztési Tanács (BAFT) is. Részben ennek következtében az agglomeráció települései szép számban képviseltették magukat, választ várva a sok éve nyitott és az új helyzetben megnyíló kérdésekre.

Már a konferencia köszöntőiben is fajsúlyos újszerủ kihívások kerültek említésre. Ahogy Hutiray Gyula főpolgármester-helyettes jelezte, az uniós kohéziós politika 2014-2020 közötti időszakra kialakított tervei a városok és tágabb térségük gazdasági erejének növelésére és munkahelyeket teremtő fejlesztésekre összpontosulnak. Tény, hogy az unióban jelentős hangsúly kerül a városfejlesztésre a 2014-et követő időszakban, és ennek kerete már egyáltalán nem a közigazgatási határok közé zárt város lesz. A komplex, több témakörre kiterjedő fejlesztések kereteit a tervezési és müködési szempontból integrált várostérségek adják majd. A jelenlegi helyzetet reálisan felmérve Budapest és térsége az integráltság elvárt szintjétől nagyon távol áll mind a tervezés, mind a projektmegvalósítás, mind az egyes szolgáltatások működtetése terén. Indokoltan fogalmazta meg Szűcs Lajos, a Pest Megyei Közgyűlés elnöke, hogy a

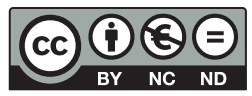


növekvő népességű agglomerációban élők ugyanazokat az életminőségre vonatkozó elvárásokat fogalmazzák meg, mint a budapestiek és minden más európai városlakó, de ehhez szükség van egy olyan várostérségre, ahol össze tudják hangolni településfejlesztési elképzeléseiket, hiszen a 2014-től kezdődő új kohéziós támogatási időszakban előnyben részesülnek a közösen pályázók. Ennek eléréséhez azonban a városra és környezetére organikus rendszerként kell gondolni.

Horváth Gyula, az MTA KRTK Regionális Kutatások Intézetének igazgatója elmondta, hogy az utóbbi évtizedekben sok országtól eltérően nem jött létre folyamatos párbeszéd a városigazgatás és a politika szereplői között a fővárosi agglomeráció integrációjának mechanizmusairól, szervezeti formáiról és fejlesztésének stratégiai kérdéseiről. Hozzátette: az új társadalomirányítási modell alkalmazása nemcsak a budapesti agglomeráció, hanem az ország érdekét is szolgálja, amihez szükség van a tudományos megalapozottságra.

A konferencia előadásai tematikus rendszert követtek. Délelőtt elsősorban az államigazgatás és a tudomány képviselői szerepeltek. Salamin Géza fooszzályvezető (NGM) A budapesti agglomeráció fejlesztési prioritásai az országos területfejlesztési irányelvek tükrében című előadásában a várostérségek együttes fejlesztésének európai dimenzióit és hazai szakpolitikai, tervezési kereteit, irányelveit taglalta. Magó Erzsébet osztályvezető (BM) a rendezési vonatkozású aktuális kereteket részletezte; előadása a konferencia vitára lehetőséget adó részében számos, konkrét településeket érintő és helyben komoly vitát kiváltó kérdést indukált. A tudomány képviselői közül Szirmai Viktória (MTA TK SZI) az agglomerálódás társadalmi következményeit, város és környéke viszonyrendszerének aktuális hazai helyzetét részletezte egy kiterjed magyarországi vizsgálat kapcsán. A gazdasági válság és annak konkrét, a budapesti agglomerációra gyakorolt hatásai sem maradtak érintetlenül. Váradi Monika Mária, az MTA KRTK RKI kutatója egy egészen friss kutatás eredményeként megállapította, hogy a Budapest környékén zajló ,....Szuburbanizáció dinamikájának csökkenése, térbeli kiterjedésének, a folyamatban részt vevők körének összeszükülése" az a jelenség, aminek tanúi vagyunk a válság következményeként. A tudományos eredmények üzenetértékűek a tervezők és a politikacsinálók számára: a koordinációra valóban szükség van.

A hosszúra nyúlt délelőtti program zárásaként az európai uniós források középmagyarországi és azon belül fóként a budapesti agglomerációban történt felhasználásának struktúráját és hatékonyságát mutatta be Gordos Tamás, a Pro-Régió ügynökség programiroda-vezetője. A vita egyik fö kérdése: Mi lesz 2014 után, milyen nagyságrendű források és milyen hozzáféréssel állnak az agglomerációs települések rendelkezésére? Gordos Tamás elmondta, hogy még csak kialakulóban vannak azok az elvek, amelyek a 2014-et követő időszak EU-forrásainak hazánkra jutó pénzügyi keretei felhasználását meghatározzák. Az viszont látható, hogy a régió Budapest által meghatározott sajátos helyzete miatt elsősorban nem az infrastrukturális, hanem az úgynevezett soft jellegü, azaz tartalomfejlesztési vonatkozású projektek kerülnek elötérbe a fövárosi agglomerációban.

A délutáni programban általános tervezési, szakági és szervezeti kérdések voltak napirenden. Schuchmann Péter, az agglomerációban hosszabb ideje területi 
és településtervezési feladatokat végző Pestterv Kft. ügyvezetője aktualitásként a területi reálfolyamatok befolyásolására alkalmas országos (és térségi) érdekeltségi rendszer jelentőségéről és az annak átalakítására vonatkozó tervezési feladatokról beszélt. Pongrácz Katalin főosztályvezető (BFÖ) a készülő Budapest városfejlesztési koncepció térségi vonatkozásairól szólt, arról, hogy határozott szándék Budapest és várostérsége közös platformjának kialakítása. Mint említette, ez több összetevőből áll, ilyen például az együttmúködés a városhatáron túlnyúló fejlesztésekben, a belső részek tehermentesítése a városkörnyékkel összefüggésben és - a mások által is hangsúlyozott - területi folyamatok befolyásolására alkalmas fejlesztési és ösztönző rendszer kialakítása. A spontán, de még inkább a jól szervezett településközi együttműködés fontosságáról szólt Pápai Mihály, a Fővárosi Agglomerációs Önkormányzati Társulás elnöke, nemzetközi példák és szervezetük működésének bemutatásával. Kiss Attila, a Pest Megyei Kormányhivataltól az átalakuló közigazgatási rendszer agglomerációs vonatkozásairól tartott beszámolót.

A konferencia kiemelt témája az agglomeráció legégetőbb problémája, a közlekedésfejlesztés és közlekedésszervezés volt. Vitézy Dávid, a Budapesti Közlekedési Központ vezérigazgatója szólt arról, hogy az elmúlt 20 évben a Budapest és agglomerációja viszonylatában jelentősen megnövekedett ingázó forgalom egyre komolyabb kihívásokat jelent. Ezekre csak oly módon adható válasz, ha a közlekedési intézkedések a fóvároson túlnyúlnak az agglomeráció területére. Kiemelkedő fontosságúnak ítélte az agglomeráció és a tágabb várostérség szereplőivel történő együttműködést, valamint konkrét, az agglomerációt érintő fejlesztési projektekről és intézkedésekről is beszélt. Ugyancsak közlekedési témájú, de már nemzetközi vonatkozású projektről szólt Koszorú Lajos, a Város-Teampannon Kft. ügyvezetője a Budapest Liszt Ferenc Repülőtér rendezéséről szóló előadásában. A hosszú távú és nagytérségi léptékben történő gondolkodás egyik példájának bemutatása és jelentőségének hangsúlyozása elgondolkodtató zárása volt a konferenciának.

A konferencián nem született zárónyilatkozat vagy a közeledés szándékát kifejező partneri felhívás. Számos kérdés továbbra is megválaszolatlan maradt, sokan mégis megelégedve távoztak, hiszen a jelenlegi helyzet változatos szemszögből történő megközelítése valóban a megoldásokhoz vezető egyik kiindulási pont lehet. Az előadások kivonatait tartalmazó kiadvány és az egyes előadások PDF-formátumú változata elérhetők a http://www.rkk.hu/hu/keti/keti/bp_agglo_konf.html weboldalon.

Köszönet az MTA KRTK Regionális Kutatások Intézete, Közép- és Észak-magyarországi Tudományos Osztálya munkatársainak a konferencia szervezésében és lebonyolításában történő részvételért.

\section{Jegyzet}

1 2012. január 1-től MTA KRTK Regionális Kutatások Intézete Közép- és Észak-magyarországi Tudományos Osztálya. 